\title{
Chapter 9 \\ Tax Expenditure Reporting and Domestic Revenue Mobilization in Africa
}

\author{
Agustin Redonda, Christian von Haldenwang, and Flurim Aliu
}

\subsection{Tax Expenditure and Tax Expenditure Reporting}

Governments pursue public policy objectives through revenue collection and public spending. However, they also rely on tax expenditures (TEs). The term refers to benefits granted to specific sectors or groups through preferential tax treatments such as exemptions, deductions, credits, deferrals and lower tax rates. Governments use TEs to promote economic growth and attract investments but also for the pursuit of social welfare objectives and to incentivise specific patterns of behaviour, such as energy consumption from renewable sources.

TEs are hence used widely as public policy instruments, and they are costly. In the United States, the federal government is estimated to forego more than USD1.5 trillion in 2019, an amount equal to $44 \%$ of tax revenue collection and slightly more than $7 \%$ of gross domestic product (GDP) (US Treasury 2020). Existing estimates, though limited in scope, show that TEs range from 0.7 to $6.6 \%$ of GDP in Latin America and from 3.3 to 7.5\% of GDP in Africa (World Bank 2015).

Yet, despite their significant fiscal cost, TEs are often very opaque. Transparency on the range and magnitude of existing TEs is limited, and new provisions are being introduced regularly without adequate scrutiny. This lack of scrutiny may sometimes be justified by the urgency of the situation. For instance, all over the world governments have introduced tax reliefs as a short-term response to the coronavirus disease

\footnotetext{
A. Redonda $(\bowtie) \cdot$ F. Aliu

Council on Economic Policies, Zürich, Switzerland

e-mail: ar@cepweb.org

C. von Haldenwang

German Development Institute, Deutsches Institut für Entwicklungspolitik (DIE), Bonn,

Germany

e-mail: christian.vonhaldenwang@die-gdi.de
} 
2019 (COVID-19) pandemic. ${ }^{1}$ However, in a majority of cases, TEs are used to pursue more strategic goals, and they tend to persist over time. This makes the issue of TE reporting and transparency a very relevant issue, particularly for low-income countries with limited capacities for domestic revenue mobilization (DRM).

Official reports on TEs are based on very heterogeneous standards both with respect to the quality and the scope of the data they provide. In France, for instance, the budget appendix dedicated to TEs explicitly acknowledges that 254 TEs out of 474 cannot be quantified, or only a rough order of magnitude can be given (Direction du Budget 2019). Switzerland published its last report on federal TEs in 2011 (Département Fédéral des Finances 2011). Australia, despite being at the forefront in terms of TE reporting, does not provide estimates for $49 \%$ of all TEs (143/289) in its Tax Expenditures Statement 2017 (Australian Treasury 2018). The picture is significantly worse when it comes to developing economies. In regions such as the Middle East and North Africa, less than $10 \%$ of the countries report on TEs on a regular basis (World Bank 2015).

As a result, TEs are hardly ever subject to sound cost-benefit analyses. Indeed, empirical studies assessing the effectiveness and efficiency of TEs are rare, and, when available, results are often not the expected ones. ${ }^{2}$ At the same time, identifying and phasing out costly and ineffective provisions are crucial in order to improve the equity and fairness of the tax system, to increase the mobilization of domestic resources and to raise the quality of public expenditure systems. TE reform has become even more crucial in the current situation, when governments will have to cope with the medium- and long-term effects of the COVID-19 crisis.

In South Africa, for instance, the government grants pension-related TEs to promote the growth of pension savings and to provide the elderly with a stable income upon retirement. According to the latest TE report, in 2016 these provisions were the largest TE in South Africa, amounting to 72,991 million Rand (ca. 5.1 billion euros), i.e. $35 \%$ of total TEs. Pension-related TEs have been at the heart of an intense debate. The South African government has been trying to deal with a policy design trade-off between providing generous benefits to boost individual savings and the risk of compromising the equity of the tax system due to the excessive use of these provisions, particularly by those at the top end of the income distribution. As acknowledged in a Technical Discussion Paper published by the South African Treasury in 2012, "the barriers to a more effective tax incentive regime are the

\footnotetext{
${ }^{1}$ An overview over tax measures taken to confront the pandemic can be found at https://www.oecd. org/tax/tax-policy/, accessed on 27.05.2020.

${ }^{2}$ For instance, many tax incentives implemented to attract investment have been proven to perform poorly. This is the case of several tax incentives granted by low-income economies such as tax holidays and special economic zones (WB 2017) as well as patent boxes (Alstadsæter et al. 2018; Klemens 2017) and other tax incentives to boost R\&D. Yet, the lack of effectiveness of TEs goes beyond tax benefits for businesses. The mortgage interest deduction (Hilber and Turner 2014) and the myriad of tax benefits to boost pension savings (Duflo et al. 2006) have also been proven to be ineffective. For a more detailed overview on the lack of effectiveness and efficiency of TEs, see Redonda (2016).
} 
complexity of the current regime [...] as well as the fact that the regime is open to abuse through excessive contributions by employers and high-income earning individuals. [...] The tax exemption has no nominal monetary cap in the case of higher-income employees, allowing them to make tax-exempt contributions way in excess of the amount required to maintain a reasonable standard of living in retirement" (South African National Treasury 2012). A comprehensive reform was implemented in 2016 to simplify and harmonise the pension system in the hope that this would improve the fairness of the whole system. Yet, as shown by Axelson et al. (2020), pension-related TEs are still highly regressive in the country.

The goal of this chapter is twofold: first, to discuss the role of TE reporting as a key component of a more effective and fairer tax system as well as a determinant for DRM and, second, to provide an overview of TE reporting in Africa.

\subsection{The Fiscal Cost and (in)Effectiveness of Tax Expenditures}

Revenue mobilisation is vital for many low- and middle-income economies. The financing gap for achieving the Sustainable Development Goals (SDGs) for developing countries alone has been estimated at roughly USD2.5 trillion (UNCTAD 2014). External financing_-including official development assistance and foreign direct investment (FDI) - is certainly an important source of revenue. Yet, the mobilisation of domestic resources should be considered the most important revenue source to support inclusive and sustained economic growth (Brys et al. 2016). Tax revenues amounted to USD4.3 trillion in 2016 for low- and middle-income countries alone, which is more than double the amount of international public and private capital these countries received in the same year (von Haldenwang and Laudage 2019).

Indeed, the mobilisation of domestic resources through taxation is particularly relevant for many reasons. Revenues collected through the tax system are generally more stable and predictable than those coming from foreign aid or domestic non-tax sources, e.g. royalties from the minerals sector. Moreover, the contribution of taxes can strengthen the social contract between citizens and their government and thus have a positive effect on governance. Unfortunately, though, tax-to-GDP ratios in many low- and middle-income economies are strikingly low. Whereas the average tax-to-GDP ratio for advanced economies is $26 \%$, about half of developing countries collect less than $15 \%$ of GDP in taxes-a threshold that has recently been identified as the minimum required to allow developing economies to take off economically (IMF 2017a).

Increasing tax revenues is an ambitious and complex task. It entails working on issues such as designing efficient tax systems, improving institutional capacity, increasing tax compliance, cooperating with other revenue bodies at an international scale and empowering tax administrations at various government levels, among 
others. Beyond these technical issues, however, fiscal contract and fiscal sociology debates show that improving tax systems is above all a systemic task that involves addressing the quality of public policies, the strengthening of governmental checks and balances and the legitimacy of government in general (Bird and Zolt 2015; Prichard 2019).

It is against this background that the frequent and sustained use of TEs should be analysed. While ideological positions may play a role, for instance, with regard to the private or public provision of social security or health insurance, it can be assumed that in most developing countries, TEs are employed for two main reasons: tax competition and political convenience. Tax competition refers to the fact that capital-hungry countries are under pressure to grant incentives for investments to the degree that this is an established practice among its competitors. Convenience means that these instruments are readily available to reward specific clientele groups or to obtain rents. This makes them an important pillar of the politics of taxation and the political economy of tax bargaining.

Phasing out ineffective TEs-which appears a low-hanging fruit for developing countries at first glance-is in fact a difficult, at times even risky undertaking. Institutional and power lock-ins evolve around specific TEs, making it politically costly to dismantle them. Public protests are widely documented in the literature, particularly with regard to fossil fuel subsidies, which often have a large impact on the costs of living of poorer urban households (for instance, see Chelminski 2018). Protests are often fuelled by a general lack of trust in government, as citizens refuse to trade present benefits for a promise of uncertain future compensations. In addition, powerful economic groups or large individual companies lobby for the extension of sector- or firm-specific tax breaks, and politicians lobby for keeping certain territorial TE schemes, such as special economic zones (SEZs), that favour their electoral districts or local constituencies (for instance, see Daude et al. 2017).

The Inter-American Center of Tax Administrations (CIAT) Tax Expenditure Database (TEDLAC) shows that, on average, TE as percentage of GDP amounted to $3.5 \%$ in the region, ranging from $0.7 \%$ in Colombia to $6.6 \%$ in Dominican Republic (Pelàez Longinotti 2018). Kassim and Mansour (2018) review TE reporting in 26 low- and middle-income economies and show that the revenue foregone through these provisions is in most of the cases significant. In their sample, TE as a share of GDP ranges from $1.38 \%$ in Burkina Faso to $4.69 \%$ in Poland and $6.13 \%$ in Ghana. Likewise, TE as a share of total tax revenue is as high as $27.8 \%$ in Poland, $41.67 \%$ in Ghana and a staggering $58 \%$ in Mauritania.

It has been argued that, despite their fiscal cost, TEs can be a valid policy instrument for governments worldwide. Indeed, under certain conditions (e.g. when eligibility conditions are directly linked to tax return data, when it is more important to maximise the number of beneficiaries than to minimize excess claims or when the policy objective is to incentivize a clear and broadly defined activity by reducing its net price), TEs could be more cost-effective than direct spending and may hence be the best option to pursue a specific public policy goal (Toder 2000). 
Yet, TE provisions are generally ineffective in reaching their stated goals. The use of tax incentives to attract investments is a case in point. Low- and middle-income economies often grant far-reaching tax holidays and tax exemptions that have little impact on investment or growth and, in addition, significantly reduce the availability of public funds (IMF et al. 2015).

To sum up, scaling back ineffective TEs would broaden tax bases and, at the same time, allow countries to reduce marginal tax rates and/or save resources that, in turn, could be allocated to more productive or more effectively targeted purposes. However, a necessary condition for a sound evaluation of the cost and impact of these provisions is data (in particular, revenue foregone estimates), which-when existent-are generally published in governmental TE reports or statements. While it is certainly true that public reporting alone is not sufficient to achieve more rationality in TE, it is hard to engage in meaningful discussion on individual TE provisions without access to reliable, detailed and timely data.

\subsection{Tax Expenditure Reporting}

Systematically identifying, estimating and reporting the fiscal cost of TEs can be a time- and resource-intensive task. As discussed by Heady and Mansour (2019), countries could adopt a gradual approach that takes their institutional and data capacities into account. The returns to such a process are potentially high, since it is critical to assess the effectiveness and efficiency of these provisions and, hence, to ensure the alignment of public policies with their stated goals. In addition, publishing comprehensive and detailed TE reports is crucial not only as a policy tool for policymakers but also as a means for increasing government transparency and accountability.

Yet, despite their significant impact on government budgets, TEs are generally much less an object of public scrutiny than direct spending. As acknowledged by the Australian Treasury, "Tax Expenditures, like direct expenditures, affect the government's budget. However, unlike direct expenditures, tax expenditures once legislated become part of the tax law with a recurring fiscal impact and do not receive regular scrutiny through the budget process" (Australian Treasury 2004). Indeed, TE reporting lags way behind best practice in most countries, and several countries that issue reports do not even estimate the revenue foregone through these provisions. An assessment of TE reporting in the 43 Group of 20 (G20) and OECD economies, based on 9 key dimensions that reflect good practice in TE reporting, shows that 8 countries have not reported on TEs in the last 10 years, 26 have published a basic report (e.g. by providing estimates for a reduced subset of TEs or estimates based on aggregate figures only) during the same period and only 9 governments have published a detailed and comprehensive TE report on a regular basis (Redonda and Neubig 2018).

Furthermore, the same assessment shows that among the 43 G20 and OECD economies, TE under-reporting (i.e. difference between the number of effectively 
estimated TEs and the number of those provisions that are listed without an estimate of their fiscal cost) is highly prevalent. For instance, the share of estimated TEs with respect to listed provisions is as low as $17 \%$ in Greece and $20 \%$ in New Zealand (Redonda and Neubig 2018). Yet, a larger ratio of estimated/listed provisions does not necessarily indicate that the report is more comprehensive. As will be illustrated with the South African example later in the chapter, the number of TEs included in the reports (estimated and/or listed) is very often far from reflecting the number of TEs effectively implemented by the government.

Moreover, while there is significant room for improving the estimation and reporting of TEs in advanced economies, the situation is even more worrisome in middle- and low-income countries. Indeed, in most of these countries, TE reporting is rudimentary at best, due to data constraints, insufficient human and financial resources as well as weak institutions, among other factors. According to figures provided by the World Bank in 2015, the percentage of countries that periodically estimates the revenue forgone through TEs amounts to 33\% in Latin America and the Caribbean, $21 \%$ in sub-Saharan Africa, 14\% in South Asia and $10 \%$ or less in the Middle East and North Africa, Europe and Central Asia as well as East Asia and the Pacific. Likewise, Kassim and Mansour (2018) show that TE reporting quality remains considerably weak in several areas in most of the 26 low- and middleincome countries covered by their study. For instance, only about half of the reviewed countries have a legal requirement to report on TEs, only three reports provide forecast estimates for future years and roughly half of the countries provide a discussion of the benchmark system in their reports. ${ }^{3}$

\subsection{Tax Expenditure Reporting in Africa}

As shown in Fig. 9.1, out of 54 African countries reviewed by the Global Tax Expenditures Database (GTED) team, 20 (about $37 \%$ of the countries) reported their TE to the public at least once between the years 2000 and $2019 .{ }^{4}$ The remaining $63 \%$ of the countries did not publish any TE reports during this period. We start our

\footnotetext{
${ }^{3}$ This information is crucial since TEs are defined as deviations from a benchmark, which represents the standard taxation treatment and, at the same time, could include certain elements of the tax system which depart from a uniform treatment of taxpayers, i.e. fundamental structural elements of the tax system such as the progressive income tax rate scale for individual taxpayers (Australian Treasury 2011).

${ }^{4}$ The GTED is a joint effort of think tanks and research institutions from Europe, Asia, Africa and Latin America, led by the Council on Economic Policies (CEP) and the German Development Institute (DIE) and financed by the German Federal Ministry for Economic Cooperation and Development (BMZ). The main goal of the project is to build the first online Global Tax Expenditures Database to increase transparency, generate trustworthy information and expand research in the field of TEs. The GTED is set up with official data on TEs published by governments worldwide, in a consistent format to increase the level of international comparability. The GTED will be made publicly available and free of charge through an online platform that will also include a
} 


\section{TE Reporting in Africa: Number of Countries}

40

35

30

25

20

15

10

5

0

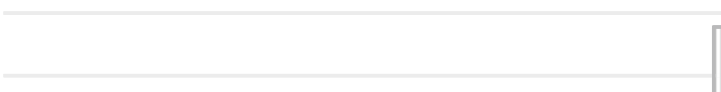

(1)

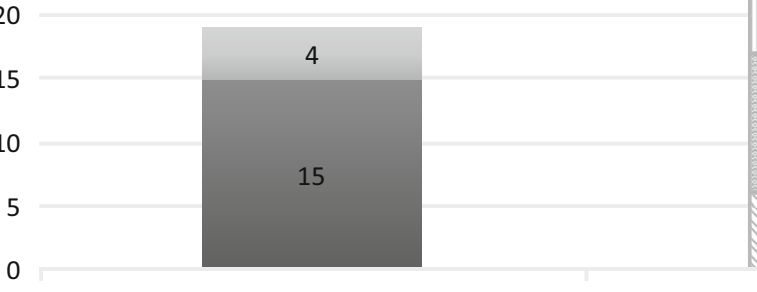

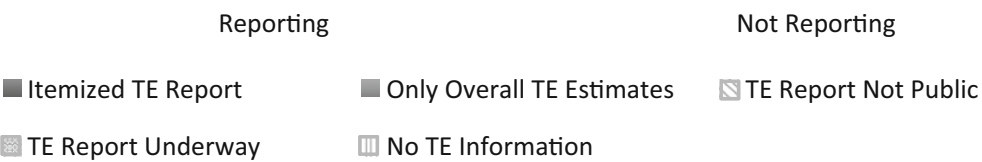

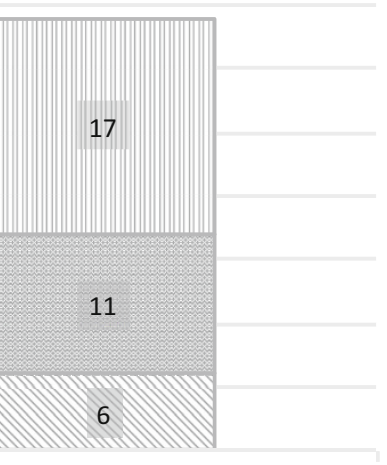

Fig. 9.1 Overview of TE reporting in Africa ("Itemized TE report" refers to TE reports that provide subcategorization beyond tax base information. The most advanced version of an itemized TE report is one that provides revenue foregone and accompanying information at the TE provision level.). Source: Global Tax Expenditures Database, www.GTED.net

discussion by taking a more detailed look at this second group before zooming in on the 20 countries that provided at least some information.

\subsubsection{African Countries Without Publicly Available TE Reports}

For the purposes of transparency and political debate, TE reports have to be public. Ideally, they should be found on open and easily accessible governmental websites or repositories. References to such reports in official government statements should include information on where to find them. For 6 out of the 34 countries classified as not having a public TE report, we found references to internal TE reports, but no further information was given. One such example is Ghana. In the FY 2019 Budget Speech, the Ghanaian Finance Minister states that "[between 2010 and 2018], about six different studies have been conducted into Ghana's tax exemptions regime by the Revenue Policy Division of the Ministry of Finance, International Monetary Fund

repository for blogs, working papers and further publications as well as events on TEs organized by the partners. For more details, see Redonda and von Haldenwang (2021). 
(IMF), Organisation for Economic Cooperation \& Development (OECD), GIZ and the World Bank" (Ministry of Finance, Republic of Ghana 2018). However, we were not able to find any of these reports. Similarly, the Eswatini (formerly known as Swaziland) Revenue Authority claims that it carries out a TE analysis biennially. "[Exemptions] under Income Taxes are reported every 2 years after carrying out a Tax Expenditure Analysis. The last report done was for 2013/14 and the next report will be undertaken in the new financial year, 2016/17" (Eswatini Revenue Authority Annual Report 2016). However, these reports are also not available.

Furthermore, 11 countries claim to be in the process of carrying out a TE analysis or are considering the possibility of doing so. Chad, for example, is reported to have started a TE analysis in 2016 but has since not published any information regarding that particular analysis or TE in general. "Since September 2016, with the support of the World Bank EFSO [Emergency Fiscal Stabilization Development Policy Operation], the [Chad] Government put a freeze on any new tax exemptions, except those under the Vienna convention or those related to PTF [Partnership Transparency Fund] until an ongoing study on tax expenditure would be completed and new measures adopted" (World Bank 2018). Similarly, Ethiopia is also reported to have a TE analysis "near completion," but additional information about the analysis is not available (IMF 2018). Table 9.1 provides information on the TE reporting state of the art in each of the assessed countries.

Lastly, the remaining 17 countries do not have any information regarding TEs on any online platform. In the case of the Central African Republic, for example, the IMF reports, "[tax] exemptions and tax expenditures are rarely detailed and assessed in the budget documentation or are maintained for several years without clear legal basis and economic justification" (IMF 2019a). Similarly, in Kenya, "[there] is no reporting of tax expenditures. Despite a constitutional requirement for a public record of tax waivers to be published, and the PFM Act's requirement for an annual report, no such reports are available" (IMF 2017b). This shows that some governments even ignore legal or constitutional norms on TE analysis and reporting.

\subsubsection{African Countries with Publicly Available TE Reports}

A total of 20 African countries reported on their TEs at least once in the last 20 years. However, the information reported during this period varies substantially across countries. Countries like the Democratic Republic of the (DR) Congo, Lesotho, Seychelles, Sierra Leone and South Sudan only provide very rudimentary estimates of TEs in budget-related documentation, without any further details. For example, in the FY 2019 Budget Speech, the South Sudan Finance Minister claimed that "exemptions have reached recorded level of sixty-nine billion South Sudanese Pounds, which deprived the government of the most resources for capital investment and development" (Ministry of Finance and Planning, Republic of South Sudan 2018). However, the ministry did not provide any information on how it calculated those estimates. This is a case that could also qualify as non-reporting. Similarly, the 
Table 9.1 Overview of TE reporting in Africa, by country

\begin{tabular}{|c|c|c|c|c|}
\hline \multicolumn{2}{|c|}{ TE report available } & \multirow[b]{2}{*}{$\begin{array}{l}\text { TE report not } \\
\text { public }\end{array}$} & \multicolumn{2}{|c|}{ TE report not available } \\
\hline $\begin{array}{l}\text { Itemized TE } \\
\text { report }\end{array}$ & $\begin{array}{l}\text { Only overall TE } \\
\text { estimates }\end{array}$ & & $\begin{array}{l}\text { TE report } \\
\text { underway }\end{array}$ & No TE information \\
\hline Benin & DR Congo & Cameroon & Algeria & Angola \\
\hline Burkina Faso & Lesotho & Ghana & Botswana & Burundi \\
\hline Ivory Coast & Seychelles & Mozambique & Chad & Cape Verde \\
\hline Gabon & Sierra Leone & Swaziland & Egypt & $\begin{array}{l}\text { Central African } \\
\text { Republic }\end{array}$ \\
\hline Guinea & South Sudan & Uganda & Ethiopia & Comoros \\
\hline Liberia & & $\begin{array}{l}\text { Equatorial } \\
\text { Guinea }\end{array}$ & Gambia & Congo \\
\hline Madagascar & & & Guinea-Bissau & Djibouti \\
\hline Mali & & & Niger & Eritrea \\
\hline Mauritania & & & Nigeria & Kenya \\
\hline Mauritius & & & Togo & Libya \\
\hline Morocco & & & Zambia & Malawi \\
\hline Rwanda & & & & Namibia \\
\hline Senegal & & & & $\begin{array}{l}\text { Sao Tome and } \\
\text { Principe }\end{array}$ \\
\hline South Africa & & & & Somalia \\
\hline \multirow[t]{3}{*}{ Tanzania } & & & & Sudan \\
\hline & & & & Tunisia \\
\hline & & & & Zimbabwe \\
\hline
\end{tabular}

Source: Global Tax Expenditures Database, www.GTED.net

Lesotho Revenue Authority Annual report includes a small section with an overall estimate on "Revenue Foregone on Tax Relief Measures," or similarly titled (Lesotho Revenue Authority Annual Report 2016). However, the report does not break down the overall TE estimate or provide a clear description on how this estimate was calculated. The General Directorate for Imports of DR Congo also publishes overall TE estimates in several of its annual reports with little accompanying information (Ministère des Finances et du Budget, Republique du Congo 2017).

In fact, only 15 African countries have ever published itemized reports. Nonetheless, as shown in Fig. 9.2, this number is steadily rising. The first TE report in Africa was published in Morocco in 2005. Two years later, Mauritius also started reporting on TEs. South Africa started reporting only in 2011. In 2018, the number of reports published in Africa reached a record of seven reports. Nonetheless, the numbers also highlight the inconsistency of TE reporting among African countries. As shown in Fig. 9.2, 10 out of the 15 African countries classified as having reported on TEs had only ever published one or two reports. Two countries (Mali and Senegal) published between three and five reports, and only three governmentsMauritius, Morocco and South Africa-publish TE reports regularly. Tanzania is a special case since it has covered 12 years of TE estimates in one single TE report. 

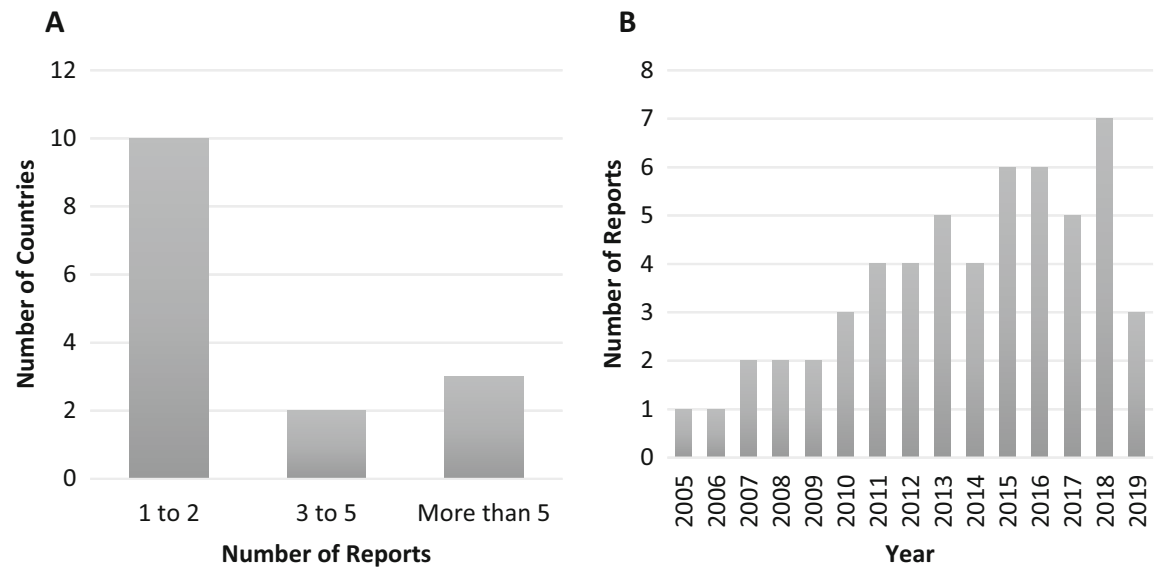

Fig. 9.2 Number of reports per country and per year. Source: Global Tax Expenditures Database, www.GTED.net

However, even for these reporting countries, much progress is needed in terms of coverage.

The quality and the scope of most TE reports do not match the standards developed, for instance, by the IMF (2019b). Morocco and Ivory Coast are notable exceptions due to the broad scope of information provided in their reports. Morocco publishes in-depth information-detailed description, legal reference, tax base, incentive mechanism, budgetary category, targeted beneficiaries, policy objective and revenue foregone - for each of its TE provisions. Ivory Coast publishes the same kind of detailed information but does only include aggregate estimates of revenue foregone. Both countries provide much of the information that can be found in the most advanced and in-depth reports of countries such as Australia and Canada. Only information regarding the number of beneficiaries of each TE provision is missing from the TE reports of these two countries.

Apart from these two cases, most of the countries with TE reports provided revenue foregone estimates that were aggregated either at the tax base or at the budgetary category level, without supplying specific information at the TE provision level. Such information would be required, however, to perform cost-benefit evaluations and hence assess the effectiveness and efficiency of these provisions. Moreover, no country presents consistent data on the number of beneficiaries per provision. ${ }^{5}$ Less than half of the countries specified the budgetary category, revealed a policy objective, specified the targeted beneficiaries or included a detailed description for each TE provision. This kind of information is not only crucial for policymakers, but it is also important to increase transparency and accountability

\footnotetext{
${ }^{5}$ Rwanda provides information on the number of beneficiaries for some provisions, but not for most. Hence, it received a negative score in the evaluation.
} 
towards the society. On the other hand, most countries did present information on methodology, the legal reference and the tax base of specific TE provisions. ${ }^{6}$

Following Kassim and Manosur (2018) and Redonda and Neubig (2018), we evaluate the TE reports of the 15 reporting countries. As shown in Table 9.2, Morocco, Burkina Faso and Ivory Coast provide the most detailed TE information at the provision level. On the other hand, Mauritius and South Africa are the countries providing the least detailed information at the provision level. However, the difference between the South African report and the Mauritian report is that the former publishes some information at the TE provision level and describes its methodology, whereas the latter only publishes an itemized table regarding TE in its budget-related documentation without any accompanying information.

Table 9.2 highlights the heterogeneity and, at the same time, the overall need for improvement in African TE reporting. For example, countries such as Mauritius, South Africa, Gabon and Liberia did not provide any information at the provision level. The Gabon report barely fits the definition of an "itemized report" as it only lists nine TE subcategories and only reports on TE from value-added tax (VAT). Moreover, countries such as Benin, Guinea, Madagascar and Senegal provide revenue foregone estimations at the provision level but do not provide any other companion information such as a policy objective. These two pieces of information are the most important when conducting cost/benefit analyses yet rarely reported together by African countries. Indeed, only 3 out of 15 African TE reports present both revenue foregone estimates and policy objectives at the TE level.

Finally, even though we observe an increase in the number of countries reporting on TEs, the overall quality of the reports has not improved across years. Reports published prior to 2018 and those published in 2018 or 2019 received roughly the same score in the evaluation. Mauritius, Morocco and South Africa are the only countries for which an individual evaluation across time is possible. The three countries show barely any change in the quality and scope of their reporting, i.e. their first and last TE reports followed the same format. While this may be an indicator of consistency, it is also obvious that a large amount of relevant information is still missing in most reports.

\subsubsection{What the Current Reports Reveal About TE in Africa}

Some key messages can be drawn from the current TE reports from Africa. Table 9.3 shows each reporting country's total TE as a percentage of the total amount of taxes collected and as a percentage of each country's GDP during the same year. On average, the revenue foregone on TE among African countries amounted to $17.8 \%$ of

\footnotetext{
${ }^{6}$ Most countries did not provide methodology information at the provision level. However, most governments that do report use only one methodology to calculate the revenue foregone for all TE provisions, which is then described in one section of the report.
} 


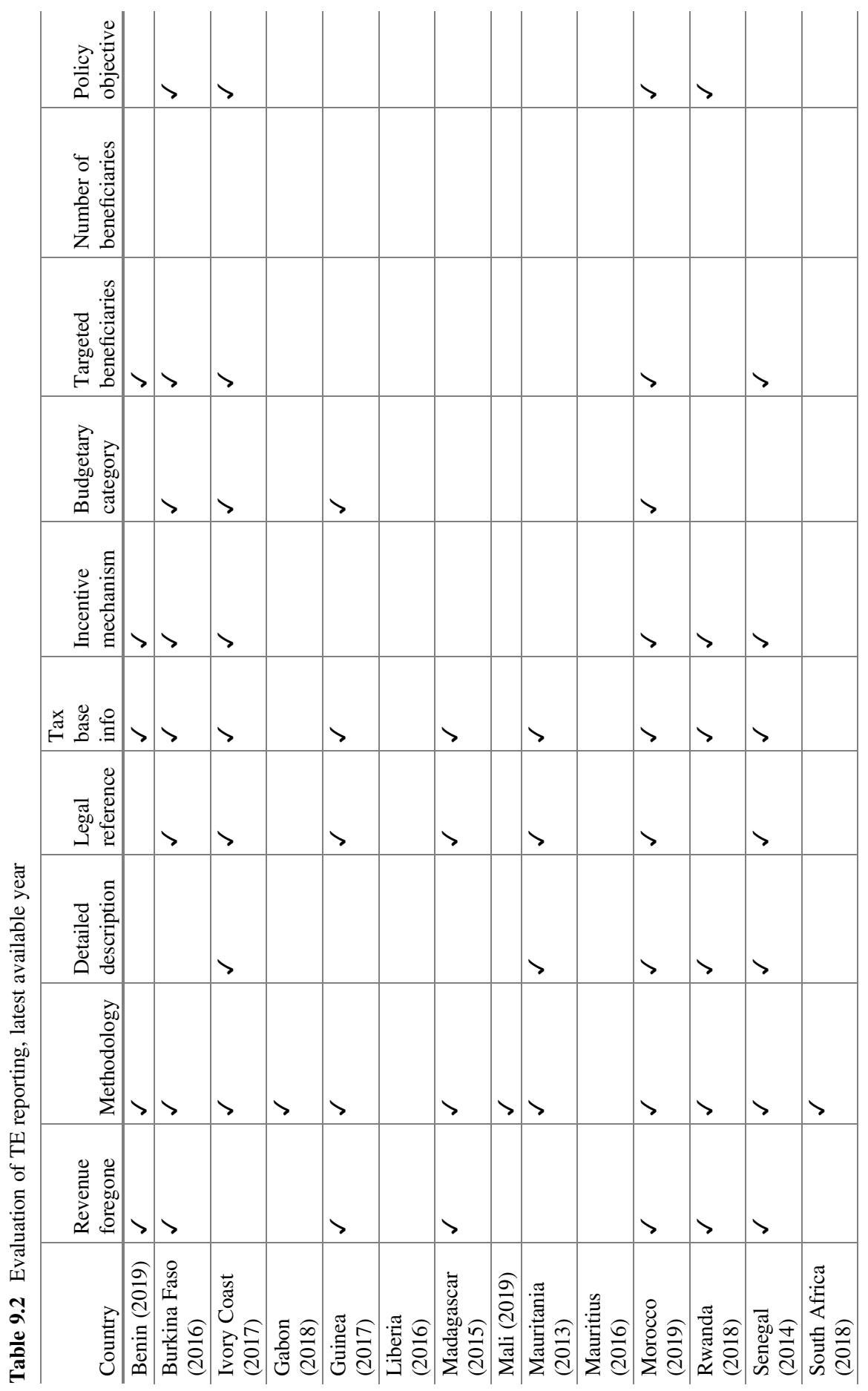




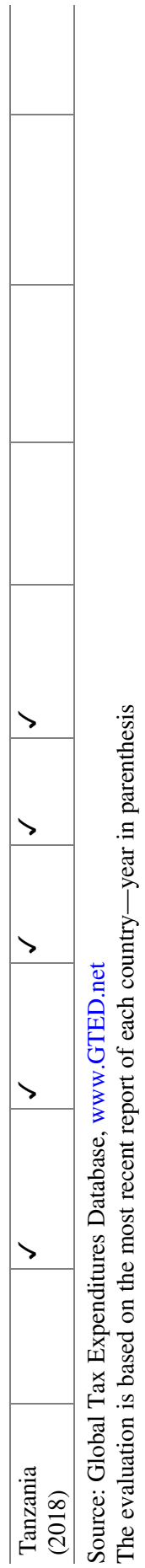


Table 9.3 TE as a percentage of total tax collected and GDP

\begin{tabular}{l|l|r|l}
\hline Country & Year & \% of tax collected & \% of GDP \\
\hline Benin & 2017 & 18.20 & 2.40 \\
\hline Burkina Faso & 2016 & 8.61 & 1.38 \\
\hline DR Congo & 2016 & 10.21 & 0.65 \\
\hline Ivory Coast & 2017 & 9.80 & 1.32 \\
\hline Gabon & 2017 & 12.10 & 1.24 \\
\hline Guinea & 2017 & 21.70 & 2.63 \\
\hline Lesotho & 2016 & 17.60 & 3.96 \\
\hline Liberia & 2016 & 18.89 & 4.70 \\
\hline Madagascar & 2015 & 17.00 & 1.79 \\
\hline Mali & 2017 & 17.32 & 2.64 \\
\hline Mauritania & 2013 & 58.41 & \\
\hline Mauritius & 2017 & 9.22 & 1.76 \\
\hline Morocco & 2018 & 13.01 & 2.78 \\
\hline Rwanda & 2018 & 14.30 & 4.60 \\
\hline Senegal & 2014 & 39.60 & 7.80 \\
\hline Seychelles & 2019 & 1.04 & 0.34 \\
\hline Sierra Leone & 2017 & 8.76 & 1.20 \\
\hline South Africa & 2017 & 14.90 & 3.90 \\
\hline Tanzania & 2012 & 27.00 & 4.40 \\
\hline Average & & 17.77 & 2.75 \\
\hline Souce: Glob & & & \\
\hline
\end{tabular}

Source: Global Tax Expenditures Database, www.GTED.net Includes the countries which provided only overall estimates South Sudan only provided an overall estimate of total "exemptions" in local currency. However, due to a drop of GDP by $80 \%$ during the same reporting year, it is hard to calculate a meaningful TE/GDP ratio. Similarly, due to a steep currency devaluation in Mauritania between 2010 and 2017, it is hard to calculate a meaningful TE/GDP ratio for that country as well

total tax collected. However, the TE share of total tax collected varied substantially across countries. In countries like Mauritania and Senegal, for example, this share was as high as $58.4 \%$ or $39.6 \%$, respectively. Meanwhile, in Burkina Faso, Seychelles and Sierra Leone, TE was less than $9 \%$ of total tax collected. Similarly, TE as a share of GDP also varied across African countries. On average, TE accounted for $2.7 \%$ of GDP across African countries. However, this share was as low as $0.3 \%$ in the Seychelles and as high as $7.8 \%$ in Senegal. Furthermore, it is important to note that some countries such as Gabon, Liberia and Sierra Leone only reported their TE for one specific tax base (VAT in the case of Gabon and customs for the rest). Hence, the share of TE in total tax collected or in total GDP for these countries is likely higher.

As shown in Table 9.4, TE across African countries came from similar tax bases. VAT expenditure comprised the largest share of TE in most African countries. On average, almost half (49\%) of TE across African countries originated from VAT-related exemptions and rate reductions. Customs duties were also a big source for TE across Africa. More than one-fifth ( $20 \%$ on average) of TE stemmed from 
Table 9.4 Share of total revenue foregone by tax base

\begin{tabular}{|c|c|c|c|c|c|c|c|c|}
\hline Country & Year & $\begin{array}{l}\text { VAT } \\
(\%)\end{array}$ & $\begin{array}{l}\text { PIT } \\
(\%)\end{array}$ & $\begin{array}{l}\text { CIT } \\
(\%)\end{array}$ & $\begin{array}{l}\text { Customs } \\
(\%)\end{array}$ & $\begin{array}{l}\text { Stamp duty } \\
(\%)\end{array}$ & $\begin{array}{l}\text { Excise } \\
(\%)\end{array}$ & $\begin{array}{l}\text { Others } \\
(\%)\end{array}$ \\
\hline Benin & 2017 & 62.7 & 0.1 & 1.5 & 10.3 & 25.0 & 0.1 & 0.3 \\
\hline $\begin{array}{l}\text { Burkina } \\
\text { Faso }\end{array}$ & 2016 & 40.7 & & 21.0 & 26.1 & 8.5 & 0.0 & 3.8 \\
\hline DR Congo & 2016 & 66.7 & & & & & & 33.3 \\
\hline Ivory Coast & 2017 & 69.6 & & 9.2 & & & 0.7 & 20.5 \\
\hline Gabon & 2017 & 100.0 & & & & & & 0.0 \\
\hline Guinea & 2017 & 40.0 & & & 34.0 & & 11.0 & 15.0 \\
\hline Lesotho & 2016 & 38.2 & 61.8 & & & & & 0.0 \\
\hline Liberia & 2016 & & & & 100.0 & & & 0.0 \\
\hline Madagascar & 2015 & 24.2 & 0.5 & 2.5 & 42.0 & & 8.0 & 22.7 \\
\hline Mali & 2017 & 60.3 & & 11.7 & 24.2 & 2.7 & & 1.1 \\
\hline Mauritania & 2013 & 49.1 & 9.6 & 4.4 & 27.1 & 0.7 & & 9.1 \\
\hline Mauritius & 2017 & 33.5 & 8.0 & 46.0 & 2.3 & & 10.2 & 0.0 \\
\hline Morocco & 2018 & 52.9 & 15.9 & 15.6 & 2.7 & 2.4 & 0.9 & 9.5 \\
\hline Rwanda & 2018 & 60.7 & & & 27.5 & & & 11.8 \\
\hline Senegal & 2014 & 45.8 & 22.5 & 11.4 & 9.7 & 2.8 & & 7.8 \\
\hline Seychelles & 2019 & 4.6 & 71.2 & 18.5 & 5.7 & & & 0.0 \\
\hline Sierra Leone & 2017 & & & & 100.0 & & & 0.0 \\
\hline South Africa & 2017 & 35.4 & 36.6 & 4.7 & 23.3 & & & 0.0 \\
\hline Tanzania & 2012 & 44.0 & & & & & & 56.0 \\
\hline
\end{tabular}

Source: Global Tax Expenditures Database, www.GTED.net

customs-related taxes. ${ }^{7}$ Income tax-related expenditure was also important, even though its significance varied by country. For example, personal income tax (PIT) expenditure was less than $1 \%$ of TE in Benin and Madagascar, while it was more than $35 \%$ in South Africa and as high as $71.2 \%$ in the Seychelles. Similarly, corporate income tax (CIT) expenditure was lower than 3\% in Benin and Madagascar but higher than $45 \%$ in Mauritius. However, the presentation of income TE varied by country. While 11 countries reported CIT and PIT separately, other countries did not differentiate between CIT and PIT. In these cases, income tax TE was included in the "other" category. Moreover, revenue foregone from excise taxes and especially stamp duties usually comprised a small portion of TE (except for stamp duty TE in the case of Benin). Lastly, taxes such as apprenticeship taxes, export taxes and other country-specific taxes also comprised a small portion of TE and were included in the "other" category.

In addition, while beneficiary information was absent from a lot of African TE reports, some insight can nonetheless be drawn from the available information. As shown in Table 9.5, businesses benefited the most from African TE. On average, a

\footnotetext{
${ }^{7}$ The numbers from Gabon, Liberia and Sierra Leone were removed when calculating those averages since these countries only reported their TE for one singular tax base.
} 
Table 9.5 Share of revenue foregone by beneficiary type

\begin{tabular}{l|l|l|l|l|l|l|l}
\hline Country & Year & $\begin{array}{l}\text { Public } \\
\text { sector }(\%)\end{array}$ & $\begin{array}{l}\text { Businesses } \\
(\%)\end{array}$ & $\begin{array}{l}\text { Households } \\
(\%)\end{array}$ & $\begin{array}{l}\text { NGOs } \\
(\%)\end{array}$ & $\begin{array}{l}\text { IGOs } \\
(\%)\end{array}$ & $\begin{array}{l}\text { Others } \\
(\%)\end{array}$ \\
\hline Benin & 2017 & 23.1 & 39.6 & 34.0 & & 1.6 & 1.7 \\
\hline $\begin{array}{l}\text { Burkina } \\
\text { Faso }\end{array}$ & 2016 & 10.1 & 75.5 & 11.3 & 0.0 & & 3.1 \\
\hline Ivory Coast & 2017 & 28.6 & 63.5 & & 0.8 & 4.3 & 2.8 \\
\hline Gabon & 2017 & & & & & & \\
\hline Guinea & 2017 & & 64.8 & 2.6 & & & 32.6 \\
\hline Liberia & 2016 & & & & & & \\
\hline Madagascar & 2015 & & 79.6 & 0.6 & & & 19.9 \\
\hline Mali & 2017 & & & & & & \\
\hline Mauritania & 2013 & & 61.4 & & & & 38.6 \\
\hline Mauritius & 2017 & & & & & & \\
\hline Morocco & 2018 & 2.7 & 47.4 & 48.4 & & & 1.5 \\
\hline Rwanda & 2018 & & & & & 7.2 & 5.4 \\
\hline Senegal & 2014 & 5.2 & 20.5 & 61.7 & & & \\
\hline South Africa & 2017 & & & & & & 74.7 \\
\hline Tanzania & 2012 & 17.1 & 7.8 & & 0.4 & &
\end{tabular}

Source: Global Tax Expenditures Database, www.GTED.net

little over 50\% of TE across African countries stemmed from exemptions and other incentives given to businesses. Households were also important beneficiaries of TE. They received a little over $25 \%$ of the TE. However, the TE share of businesses and households in some countries is even higher since they reported the TE given to those two beneficiaries jointly, on top of reporting their individual shares (in such cases, the joint share is added to the "other" category in Table 9.5). Moreover, while the government was often an important beneficiary of TE, intergovernmental organizations (IGOs) and non-governmental organizations (NGOs) were usually not. Lastly, country-specific beneficiaries such as the mining sector or TE provisions with missing beneficiary information were categorized as "other."

Yet, it is important to note that the numbers reported in Tables 9.3, 9.4 and 9.5 must be interpreted with caution. As shown in Fig. 9.3, countries do not estimate the revenue foregone for all TE provisions they report. Hence, the numbers reported above either understate or overstate the significance of some categories and the total magnitude of TE. For example, while two-fifths of the sample countries do not specify the share of TE provisions evaluated, some countries such as Benin and Madagascar report that they evaluated less than $50 \%$ of their TE provisions. Burkina Faso and Mauritania report that they evaluated around $60 \%$ of their TE provisions. Lastly, Ivory Coast, Guinea, Morocco and Senegal report having evaluated $70 \%$ or more of the TE provisions identified in their tax codes. However, even if the countries claim to have evaluated the revenue foregone from a majority of their provisions and their TE/GDP ratio may seem realistic, often, a portion of their TE provisions is not included in their reports. 


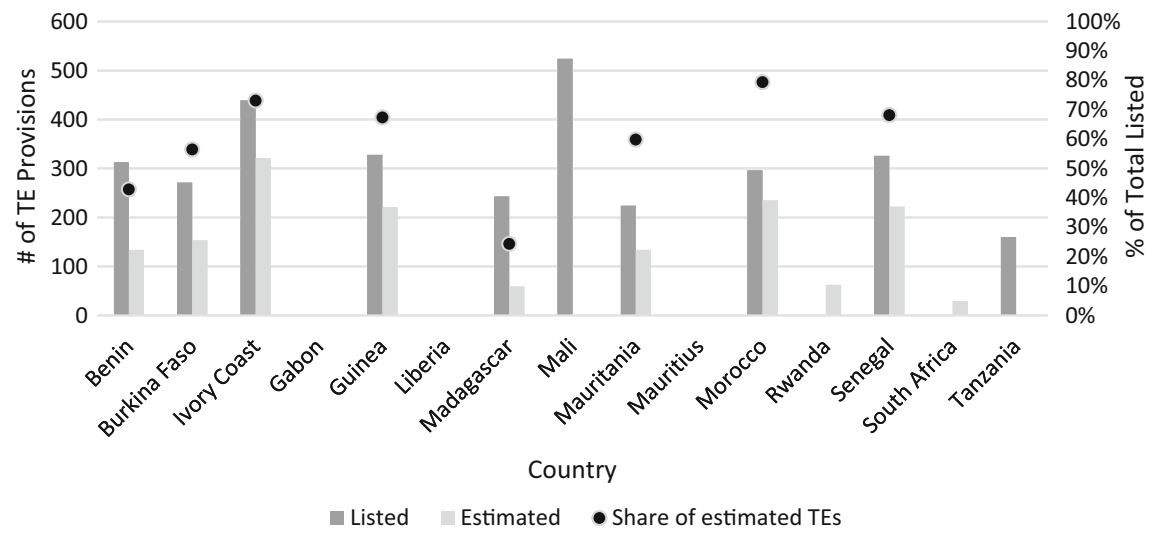

Fig. 9.3 Percentage of TE provisions evaluated. Source: Global Tax Expenditures Database, www. GTED.net

South Africa is a case in point. The latest TE statement published by the treasury reports estimates for 34 provisions, 13 TEs granted through PIT, 9 through CIT, 7 through VAT and 5 through customs and excise taxes. Total TEs in 2016, the latest available year, were estimated at Rands 209,007 accounting for $18.3 \%$ of total gross tax revenue and $4.7 \%$ of GDP.

Yet, these figures should be interpreted cautiously since the statement does not include several TEs. For instance, individuals working overseas for a 183-day term can claim back tax deductions on income earned for the period they were outside the country. In addition, as PTEs, tax-free savings accounts (TFSAs) aim at boosting individuals' savings by fully exempting the money invested into a TFSA from any tax on interests, dividends, capital gains and withdrawals. Moreover, individuals can deduct various work-related expenses. For example, individuals using their vehicle for work purposes can also claim a deduction. The depreciation on devices (e.g. laptops, smart phones) bought and maintained in one's personal capacity for work may also be claimed as a tax deduction. Finally, employers that work from home on a regular basis and in a specifically dedicated space are also allowed to claim certain running costs associated to that space, including rent, electricity and maintenance expenses.

When it comes to businesses, income from international shipping of a resident company that holds a share in a South African-flagged ship is exempt from CIT. Moreover, the Headquarter Company (HQC) Regime eliminates multiple fiscal and regulatory barriers to encourage foreign investors to use South Africa as a holding company/HQC jurisdiction. Among other benefits, this regime exempts eligible businesses from dividends tax and capital gains taxes. Finally, as in several lowand middle-income economies, South Africa created several SEZs, i.e. designed areas for targeted economic activities where a myriad of tax benefits are in place. These benefits include a reduced $15 \%$ CIT rate (compared to the standard $28 \%$ rate), 
a $10 \%$ building allowance, an employment tax incentive as well as additional VAT and duties reliefs for firms operating within a customs-controlled area of an SEZ. ${ }^{8}$

The list of existing TEs that are not covered by the TE statement is likely to be much broader for other countries as well. A first step towards a more transparent reporting on TEs would be to include all existing provisions even when, for some of them, revenue foregone estimates are not provided. Ideally, the report will progressively increase the number of estimated provisions in order to increase transparency and accountability.

\subsection{Conclusion}

This chapter has discussed the role of TE reporting as a key component of a more effective and fairer tax system. In addition, it has given an overview of TE reporting in Africa, based on data provided by the GTED. With few exceptions, TE reporting is at a very initial stage in most countries of the region. As a result, citizens and political decision-makers in a majority of African countries do not have access to timely and detailed information on a set of highly relevant policy instruments that cause major drains to the public budget and, consequently, cannot assess the costs and benefits that these provisions generate for society. With anecdotal evidence dominating the public debate, under-reporting of existing TE regimes tends to further undermine the legitimacy and perceived fairness of taxation.

While Africa is the only region fully covered by the GTED at this moment, it is not at all clear that the other world regions perform significantly better. On the one hand, TE reporting is much more widespread in Latin America, as data presented by CIAT shows. ${ }^{9}$ On the other hand, other regions-Asia in particular-are rather uncharted territory in terms of TE reporting as well. Even among the OECD and G20 countries, the frequency and quality of reports are highly heterogeneous, as Redonda and Neubig (2018) observe.

It should be noted, however, that the TE topic has recently attracted more attention by scholars, international organisations and civil society. Efforts such as the Latin America Tax Expenditure Research, Advocacy, and Learning (LATERAL) project led by the International Budget Partnership (IBP) ${ }^{10}$ aim at covering existing knowledge gaps and raising public awareness of the issue. Several international organisations have produced reports and guidelines that aim at improving $\mathrm{TE}$ reporting (for instance, see IMF 2019b). Yet, much more remains to be done. What is still missing at this stage is decisive action to agree on joint international standards for the robust, public, exhaustive and timely assessment of the costs and

\footnotetext{
${ }^{8}$ Although the total fiscal cost of SEZs is difficult to be estimated, some of these provisions such as the Employment Tax Incentive (ETI) may be included in the TE Statement.

${ }^{9}$ See https://www.ciat.org/tax-expenditures/?lang=en, accessed 13.09.2019.

${ }^{10}$ See https://www.internationalbudget.org/analysis-insights/lateral-project/, accessed 18.09.2019.
} 
benefits of TEs. We believe that the GTED will make a substantial contribution towards this end.

\section{References}

Alstadsæter, A., Barrios, S., Nicodeme, G., Skonieczna, A., \& Vezzani, A. (2018). Patent boxes design, patents location, and local R\&D. Economic Policy, 33(93), 131-177.

Australian Treasury. (2004). Tax expenditures statement 2003. https://treasury.gov.au/publication/ tax-expenditures-statement-2003

Australian Treasury. (2011). Tax expenditures statement 2010. https://treasury.gov.au/publication/ tax-expenditures-statement-2010/tax-expenditures-statement-2010

Australian Treasury. (2018). Tax expenditures statement 2017.https://treasury.gov.au/sites/default/ files/2019-03/2017-TES.pdf

Axelson, C., Pomeranz, D., \& Redonda, A. (2020). The distributive impact of pension-related tax expenditures in South Africa. mimeo.

Bird, R. M., \& Zolt, E. M. (2015). Fiscal contracting in Latin America. World Development, 67, 323-335.

Brys, B., Perret, S., Thomas, A., \& O'Reilly, P. (2016). Tax design for inclusive economic growth. OECD Taxation Working Paper 26. OECD Publishing.

Chelminski, K. (2018). Fossil fuel subsidy reform in Indonesia. In J. Skovgaard \& H. van Asselt (Eds.), The politics of fossil fuel subsidies and their reform (pp. 193-211). Cambridge: Cambridge University Press.

Daude, C., Gutierrez, H., \& Melguizo, A. (2017). Doctoring the ball: The political economy of tax incentives for investment in the Dominican Republic. Journal of Economic Studies, 44(1), 2-23. https://doi.org/10.1108/JES-05-2015-0090.

Département Fédéral des Finances. (2011). Quels Sont les Allégements Fiscaux Accordés par la Confédération? Département Fédéral des Finances (DFF) de la Confédération Suisse (in French). https://www.estv.admin.ch/dam/estv/fr/dokumente/allgemein/Dokumentation/ Zahlen_fakten/berichte/2011/Welche\%20Steuerverg\%C3\%BCnstigungen\%20gibt\%20es\% 20beim\%20Bund\%20Bericht.pdf.download.pdf/2011_Steuerverguenstigung_f.pdf

Direction du Budget. (2019). Évaluations des Voies et Moyens. Tomme II. Dépenses Fiscales. Annexe au Projet de Loi des Finances pour 2019 (in French). https://www.performancepublique.budget.gouv.fr/sites/performance_publique/files/farandole/ressources/2019/pap/pdf/ VMT2-2019.pdf

Duflo, E., Gale, W., Liebman, J., Orszag, P., \& Saez, E. (2006). Saving incentives for low- and middle-income families: Evidence from a field experiment with H\&R block. The Quarterly Journal of Economics, 121(4), 1311-1346.

Eswatini Revenue Authority. (2017). Eswatini revenue authority annual report, 2016. http://www. sra.org.sz/documents/ANNUAL\%20REPORT\%202016.pdf

Heady, C., \& Mansour, M. (2019). Tax expenditures and their use in fiscal management: A guide to developing countries. How to Note 19/01, International Monetary Fund (IMF). https://www. imf.org/ /media/Files/Publications/HowToNotes/HTNEA2019002.ashx

Hilber, C., \& Turner, T. (2014). The mortgage interest deduction and its impact on homeownership decisions. Review of Economics and Statistics, 96(4), 618-637.

IMF. (2017a, April). Fiscal monitor. Achieving more with less. IMF. http://www.imf.org/en/ Publications/FM/Issues/2017/04/06/fiscal-monitor-april-2017

IMF. (2017b). Kenya fiscal transparency evaluation. International Monetary Fund. https://www. imf.org/external/pubs/ft/scr/2016/cr16221.pdf 
IMF. (2018). The federal Democratic Republic of Ethiopia staff report for the 2017 article IV consultation. International Monetary Fund. https://www.imf.org/ /media/Files/Publications/ CR/2018/cr1818.ashx

IMF. (2019a). Central African Economic and Monetary Community (CEMAC): Selected issues. A regional approach to enhancing governance and reducing the potential for corruption. International Monetary Fund. https://www.elibrary.imf.org/view/IMF002/25705-9781484392843/ 25705-9781484392843/25705-9781484392843_A001.xml?redirect=true

IMF. (2019b). Tax expenditure reporting and its use in fiscal management. A Guide for Developing Economies How To Notes 19/01. Washington, DC: International Monetary Fund.

IMF, OECD, UN, \& World Bank. (2015). Options for low income countries' effective and efficient use of tax incentives for investment. A Report to the G-20 Development Working Group. https:// www.imf.org/external/np/g20/pdf/101515.pdf

Kassim, L., \& Mansour, M. (2018). Les Rapports sur les Dépenses Fiscales des Pays en Développement : Une Evaluation. Revue d'économie du développement, 26(2), 113-167. (in French).

Klemens, B. (2017). Intellectual property boxes and the paradox of price discrimination. CEP Working Papers 1703, Council on Economic Policies (CEP).

Lesotho Revenue Authority. (2017). Lesotho revenue authority annual report 2016. http:// passthrough.fw-notify.net/download/860771/http://www.lra.org.ls/sites/default/files/2018-02/ LRA\%20Annual\%20Report\%20-\%202016.pdf

Ministère des Finances et du Budget, Republique du Congo. (2017). Loi de Finances 2018 (French). https://www.finances.gouv.cg/fr/loi-de-finances-2018

Ministry of Finance and Planning, Republic of South Sudan. (2018). Budget speech FY 2018/19. http://grss-mof.org/wp-content/uploads/2018/09/Budget-Speech-Final-July-12-_-12-05-pm.pdf

Ministry of Finance, Republic of Ghana. (2018). The budget statement and economic policy of the government of Ghana for the 2019 financial year. http://www.mofep.gov.gh/sites/default/files/ budget-statements/2019-Budget-Statement-and-Economic-Policy_.pdf

Pelàez Longinotti, F. (2018). Overview of tax expenditures in Latin America: Main statistics of the CIAT database. Working Paper, Inter-American Center of Tax Administrations (CIAT).

Prichard, W. (2019). Tax, politics, and the social contract in Africa. Oxford: Oxford University Press.

Redonda, A. (2016). Tax expenditures and sustainability. An overview. CEP Discussion Note 16/03, Council on Economic Policies (CEP).

Redonda, A., \& von Haldenwang, C. (2021). CEP/DIE Companion to the Global Tax Expenditures Database, GTED WP 2021/1. mimeo.

Redonda, A., \& Neubig, T. (2018). Assessing tax expenditure reporting in G20 and OECD economies. CEP Discussion Note 2018/3, https://www.cepweb.org/assessing-tax-expenditurereporting-in-g20-and-oecd-economies/

South African National Treasury. (2012). Improving tax incentives for retirement savings. Technical Discussion Paper E for Public Comment. http://www.treasury.gov.za/comm_media/press/ 2012/Improving\%20tax\%20incentives\%20for\%20retirement $\% 20$ savings.pdf

Toder, E. (2000). Tax cuts or spending-Does it make a difference? National Tax Journal, 53, 361-371.

UNCTAD. (2014). World investment report 2014. Investing in the SDGs: An action plan. United Nation Conference on Trade and Development (UNCTAD). https://unctad.org/en/ PublicationsLibrary/wir2014_en.pdf

US Treasury. (2020). Tax expenditures. https://home.treasury.gov/policy-issues/tax-policy/taxexpenditures

von Haldenwang, C. , \& Laudage, S. (2019). Financing for development and domestic revenue mobilisation: More international reforms are needed. Briefing Paper 13/2019. Bonn: DIE.

World Bank. (2015). World Bank East Asia and Pacific Economic Update. Staying the course. World Bank (WB). http://pubdocs.worldbank.org/en/414911444005973491/pdf/EAP-Eco nomic-Update-2015-10.pdf 
World Bank. (2017). Special economic zones in the Dominican Republic: Policy considerations for a more competitive and inclusive sector: Special economic zones, global value chains, and the degree of domestic linkages in the Dominican Republic (Spanish), http://documents.worldbank. org/curated/en/734421487332577036/Special-economic-zones-global-value-chains-and-thedegree-of-domestic-linkages-in-the-Dominican-Republic

World Bank. (2018). Republic of chad, first economic recovery and resilience development policy operation. World Bank. http://documents.worldbank.org/curated/en/416901537280719716/ pdf/116242-PGD-OUO-9-Chad-1st-Economic-Recovery-Resilience-DPO-PD-August-14.pdf

Open Access This chapter is licensed under the terms of the Creative Commons Attribution 4.0 International License (http://creativecommons.org/licenses/by/4.0/), which permits use, sharing, adaptation, distribution and reproduction in any medium or format, as long as you give appropriate credit to the original author(s) and the source, provide a link to the Creative Commons license and indicate if changes were made.

The images or other third party material in this chapter are included in the chapter's Creative Commons license, unless indicated otherwise in a credit line to the material. If material is not included in the chapter's Creative Commons license and your intended use is not permitted by statutory regulation or exceeds the permitted use, you will need to obtain permission directly from the copyright holder.

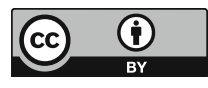

